\title{
Adverse Selection in Health Insurance Coverage of Figh-Cost Cures
}

by Paul Melmeyer

\footnotetext{
The following paper examines adverse selection concerns facing health insurance companies from the coverage of high-cost, but highly-effective, cures for chronic diseases. This problem has arisen over the past several years with the development of Sovaldi, a cure for hepatitis C. However, it will become more prevalent as more expensive cures, particularly gene therapies, are developed and come to market. Health insurers, when deciding to cover the expensive cures, incur the risk that a disproportionate number of high-cost individuals will enroll in their plan while they are ill, but leave once they are cured and healthy. This adverse selection problem may lead health insurers to avoid risking this possibility, and as a result not cover the cures at all. Policymakers have posited several solutions to address this market failure. One potential policy solution is the establishment of a risk-stabilization program for insurance plans that cover these therapies. This riskstabilization program would de-risk the potential adverse selection and allow chronically ill patients to access revolutionary, curative therapies. A second potential policy solution is the institution of annuity-like "pay-for-performance" models in which insurers pay for expensive but curative treatments over several years, contingent on the treatment's performance.
} 


\section{INTRODUCTION}

The passage of the Affordable Care Act (ACA) in 2010 brought with it the promise of quality healthcare for those who previously could not afford it. Patients with intractable, chronic diseases celebrated the prohibition of health insurance companies from discriminating against patients with pre-existing conditions. Patients who were previously unable to obtain health insurance greeted the enactment of the law with the high expectations that they would now be able to gain affordable access to treatment and therapies that they previously could not obtain (Adult Congenital Heart Association et al. 2010).

Insurers are now required to offer health insurance to any individual seeking insurance, and insurers must comply with various minimum coverage requirements. Each state must select a benchmark plan that covers ten essential health benefit (EHB) categories of care, including hospitalization, preventative and wellness care, and prescription drugs (CCIIO 2015). Each plan sold within the individual and small group markets must offer coverage within these ten categories.

There are also coverage requirements within each EHB category. For example, prescription drug plans are required to cover at least one drug in each United States Pharmacopeia (USP) drug class and/or category (CCIIO 2015). These USP Medicare Model Guidelines were created to stratify available therapies into therapeutic areas, and ensure that at least one therapeutic option for a particular condition was covered by each Medicare prescription drug plan (PDP) (United States Pharmacopeia 2015). The same guidelines are used to ensure equitable coverage in health insurance marketplace plans (Academy of Managed Care Pharmacy 2013).

Unfortunately, patients with chronic diseases are still having trouble obtaining these necessary treatment due to health insurance practices that are still allowable following the enactment of the ACA (I AM (Still) ESSENTIAL 2014). Insurers are able to effectively discriminate against high-cost patients to discourage them from joining the insurer's plan through techniques such as high patient cost-sharing for certain medications, step therapy and prior authorization mandates, limited provider networks, and formulary management (Lotvin et al. 2014; I am essential 2016).

For many patients, these insurance difficulties are almost enviable because scientific advances in therapeutic development have not caught up with their diseases, leaving them with no treatment options. This may soon change because science is catching up in the form of gene therapy. Gene therapies hold the promise of curing these intractable diseases, but they also carry a huge price tag, potentially costing over $\$ 1$ million for a course of treatment. Such expensive therapies will only exacerbate health insurers' concerns over the cost of covering of these therapies, largely because those who are responsible for covering these cures face a slew of adverse selection concerns due to highcost patients seeking high-cost cures (Cutler and Zeckhauser 1997). What is unique to the coverage of these cures, and what is even more concerning for insurers, is the possibility that these patients may leave the plan for a cheaper alternative plan once cured, potentially leaving only high-cost patients in the plan and igniting the insurance "death spiral" (Brennan and Wilson 2014). Not only would insurers 
face adverse selection concerns, but profitmaximizing insurers would need to ensure that the return on investment would cover the cost of coverage within a reasonable time frame in order to justify coverage. ${ }^{1}$ Insurers may therefore choose not to cover these therapies at all within their formularies. Even with the advancement in science, we may be left with the same problem chronic disease patients faced before the ACA was passed: limited or no access to potentially highly effective treatments.

Using the chronic disease hepatitis $\mathrm{C}$, and its curative drug Sovaldi, this paper explores the current environment of chronic diseases, the promise of cures, and the adverse selection concerns of insurers. This paper reviews options for addressing this problem, and concludes with a discussion on how the federal government could intervene to correct this market failure through the establishment of a riskstabilization program, or an annuity-like "pay-for-performance" reimbursement model.

\section{CURRENT LANDSCAPE FOR THE TREATMENT OF CHRONIC DISEASES}

The current treatment and financing landscape for chronic diseases is grim. Once diagnosed, a patient faces a lifetime of treatments ranging from non-invasive, inexpensive, and minor pharmaceutical regimens to invasive, expensive, and arduous treatment regimens that combine the full range of healthcare options over the course of the individual's lifetime. For

1 While this is certainly a relevant concern among insurers, this topic requires its own paper, and is not included within the scope of this paper. example, asthma, a chronic pulmonary disease affecting millions of Americans, is a largely inexpensive, mild, and treatable disease. Still, asthma costs the healthcare system billions of dollars per year due to its prevalence (CMS 2015). On the other end of the spectrum are genetic disorders that require a lifetime of intensive treatment and constant care to survive. These diseases can cost hundreds of thousands of dollars per year in drug spending alone (Silverman 2013). Altogether, chronic conditions are extremely costly to the healthcare system. The Centers for Disease Control and Prevention (CDC) estimate that the US spends 86 percent of all healthcare spending on the treatment of chronic diseases (CDC 2015).

Prior to recent advances, hepatitis C was an incurable chronic disease spread through contaminated blood. This disease required a lifetime of treatment costing approximately $\$ 1,987$ per month, and often approximately $\$ 739,100$ for a liver transplant and accompanying immunosuppressants if the disease worsened significantly (Milliman 2014; Bentley 2014). The course of treatment for a hepatitis $\mathrm{C}$ patient was arduous, expensive, and often ineffective. Even with the hundreds of thousands of dollars spent for each hepatitis $C$ patient, this disease slowly led to liver failure, killing approximately 15,000 people per year (CDC 2015).

Many in the healthcare system celebrated the release of Sovaldi, a drug hailed as the cure for hepatitis C. Sovaldi was approved by the Food and Drug Administration in December 2013 with the promise of an approximately 90 percent cure rate in only three months of treatment (Gilead Sciences 2015). However, the $\$ 84,000$ wholesale price tag attached to 
the three-month regimen, approximately $\$ 1,000$ per pill, shocked many within the healthcare community, causing them to accuse Gilead Sciences, Sovaldi's maker, of price gouging (Loftus 2014). Gilead has since lowered the price for most patients to approximately $\$ 54,000$ per individual through negotiated discounts with insurers (Silverman 2015). Regardless, this ignited the still ongoing debate over the appropriate cost for a cure (Millman 2014).

This debate will only become more relevant as gene therapies are developed and approved to treat chronic genetic conditions. Gene therapies, which will target specific and mostly rare genetic abnormalities, will carry a huge price tag (Johnson and Dennis 2015). The first gene therapy to enter the market in Europe, Glybera, which treats the ultra-rare disease Lipoprotein Lipase Deficiency (LPLD), will cost approximately $\$ 1.4$ million for a 42-injection course of treatment (Burger 2014). Even with the high price, Glybera carries the promise of greatly reducing the disease's severity, thus largely avoiding a lifetime of further treatment. Glybera is just the first of many gene therapies that will soon enter the market and likely carry a similarly high cost.

The cost of gene therapies is relevant to the US health insurance community as they will be expected to cover these cures in their health insurance plans. While they have yet to encounter the price tag of gene therapies (there are no gene therapies approved yet in the US; Glybera is only approved in Europe), experience from the introduction of Sovaldi has provided an indication of how insurance companies might react to the high cost of gene therapies. The price of Sovaldi caused an uproar, with some insurers refusing to cover the drug altogether (Appleby 2014). Health insurers point the finger at Gilead, while drug makers and patients accuse health insurers of discriminating against sick patients and ignoring the promise of these cures (AHIP Coverage 2014; Heavey 2014). This market failure has proved a barrier to patients with hepatitis $C$ in accessing the cure.

\section{ADVERSE SELECTION IN HEALTH INSURANCE MARKETS}

The reasons for health insurers' hesitation to cover Sovaldi go beyond just the upfront costs of the medication. Insurers may also be concerned about adverse selection, particularly the uncertainty of whether the beneficiary will stay on the same insurance plan following the end of treatment.

Adverse selection occurs when a specific plan's participants are more expensive than the general insurance pool, placing the plan at a competitive disadvantage. As it pertains to health insurance, adverse selection results from more high-cost individuals choosing to join one particular plan relative to other plans (Cutler and Zeckhauser 1997). This can arise from the plan's coverage structure being particularly favorable for high-cost individuals. It can also arise simply by chance without any discernable reason. Regardless, insurers are concerned about adverse selection in their particular plan because a firm's "costs associated with providing insurance are the expected insurance claims - that is, the expected payouts on policies" (Einav and Finkelstein 2011). Insurers then cover these costs by dividing up the total cost of the pool into 
premiums that each individual pays. The higher the costs of the pool, the higher the premium each individual pays (Cutler and Zeckhauser 1997).

For example, suppose an insurance market consists of only two firms offering identical health insurance plans, Firm $A$ and Firm B, and each firm has some hepatitis $\mathrm{C}$ patients, some low-cost individuals, and others who fall throughout the cost spectrum. Firm A's beneficiaries are generally less costly and have fewer high-cost individuals within the plan. Firm B's average beneficiary cost is higher due to a higher number of hepatitis $C$ patients and other high-cost individuals within the plan. Thus, for Firm B to maintain actuarial soundness ("projected premiums in the aggregate... are adequate to provide for all expected costs" [Actuarial Standards Board 2015]), it must charge a higher premium to its population base than Firm A. ${ }^{2}$

When healthy beneficiaries see that Firm A's premiums are less expensive than Firm B's, they will switch to Firm A's plan. While individuals do not have complete autonomy as to when they may change health insurance plans due to the presence of open enrollment periods, they can (and often do) switch plans fairly regularly when they are able to do so (Denenberg et al. 1964). Thus, when healthier consumers choose to leave the plan, "the result is that the average medical condition of insurance applications deteriorates as the price level rises" (Akerlof 1970). As the premium continues to rise and healthier individuals continue to depart, only the

2 This is assuming all other structures of the plan (deductible, cost-sharing, provider network, formulary, etc.) are identical. In the real world this is never the case, but these factors must be controlled for in order to illustrate the adverse selection concerns. costliest beneficiaries will remain on the plan, resulting in premiums increasing to the point that "no insurance sales may take place at any price" (Akerlof 1970; Dickerson 1959). The plan has then succumbed to the dreaded "death spiral" that each health insurer strives to avoid.

\section{THE EFFECTS OF ADVERSE SELECTION ON CHRONIC DISEASE PATIENTS}

To protect themselves against costs stemming from adverse selection issues, health insurance companies previously used the risk selection practice of rejecting high-cost individuals with pre-existing, chronic conditions. However, under the ACA, health insurance companies are no longer allowed to refuse coverage to individuals with pre-existing conditions. Since insurers are now "blind" to the individual's costs before signing up, "firms must offer a single price for pools of observationally identical but in fact heterogeneous individuals" (Einav and Finkelstein 2011). The regulations adopted under the ACA "require 'community rates' that are uniform across all individuals" (Einav and Finkelstein 2011).

Health insurers now use other means to discourage high-cost patients from joining their plan, mainly through coverage and plan design. Insurers are increasingly using utilization and formulary management tools to increase the patient's financial burden for high-cost medications, deterring consumers from signing up for the plan (Lotvin et al. 2014). These methods include prior authorization and step therapy (physicians must first gain the insurer's permission to prescribe a certain medication), adverse tiering within 
the plan's formularies (certain medications carry a heavier financial burden for the consumer than others to deter use of certain drugs), and the exclusion of entire therapies from the prescription drug plan's formulary (Lotvin et al. 2014). These barriers allow insurance companies to deter high-cost patients from signing up for their plans.

These practices are particularly prevalent for chronic diseases. Drugs that treat rheumatoid arthritis, certain cancers, Crohn's and colitis, multiple sclerosis, lupus, and certain rare conditions often face high cost-sharing requirements, and patients looking to access these drugs often choose plans that offer the lowest cost-sharing for these therapies. This has caused an explosion in the adoption of utilization management techniques over the past several years, particularly in exchange plans (Avalere Health 2014). Insurers do not want to end up like Firm $\mathrm{B}$ in the example above, with a higher percentage of high-cost patients requiring the firm to charge higher premiums. Instead, insurance companies implement utilization management techniques, often requesting that the patient pay upward of 50 percent of the cost of a prohibitively expensive drug (up to the out-of-pocket maximum), or excluding the drug from their formulary.

\section{EXPENSIVE CURES FOR CHRONIC DISEASE PATIENTS}

Health insurance treatment of Sovaldi follows a slightly different model. In the above cases, insurers hope to deter high-cost patients from enrolling not just because of their inherent high costs, but also because of the intractableness of their condition. However, patients seeking Sovaldi will presumably only remain "highcost" for the duration of their 12-week course of treatment. Following their "cure", they could very well be low-cost patients, and could be attractive as customers who actually drive down premiums. Adverse selection problems of a slightly different nature deter insurance plans from covering these short-term curative treatments. Insurers may be worried that if they cover the treatment, patients will leave the plan for a less expensive plan that does not cover the treatment immediately following their cure.

Firm A and Firm B can again be used as an example. In this hypothetical market, Firm A does not cover Sovaldi and Firm $\mathrm{B}$ does. There are 600 individuals in the market, spread out evenly among the high, medium, and low-cost groups. High-cost individuals incur $\$ 300$ of medical care, medium-cost individuals incur $\$ 200$ of medical care, and low-cost individuals incur $\$ 100$ of medical care. If Firm A and Firm B each have an equal distribution of high, medium, and low-cost individuals in their plans, the average cost of care is \$200 per individual for each plan. Without considering administrative costs and insurer's profit, the annual premium of each plan should equal the average estimated medical payout, which is $\$ 200$.

Now let's assume that within the 200 high-cost patients, 10 patients have hepatitis C. If there were originally five hepatitis C patients for each plan, but Firm B started covering Sovaldi, the five hepatitis $C$ patients from Firm A would switch to Firm B during open enrollment so that their Sovaldi prescriptions would be covered. At this time, Firm B would 
have 105 high-cost patients, 100 mediumcost patients, and 100 low-cost patients, all paying a monthly premium of $\$ 201.64$, again ignoring administrative costs and profit. ${ }^{3}$ Firm A would have 95 high-cost patients, 100 medium-cost patients, and 100 low-cost patients, all paying a premium of $\$ 198.31 .^{4}$

Once the hepatitis $\mathrm{C}$ patients completed their Sovaldi regimen, seeing that Firm A (or a similar plan that has open enrollment at the time) offers lower premiums, they may leave Firm B for Firm A. Now the breakdown is 95 high-cost patients, 100

3105 high-cost patients at $\$ 300$ each, 100 medium-cost patients at $\$ 200$ each, and 100 lowcost patients at $\$ 100$ average to $\$ 201.64$ per patient. 495 high-cost patients at $\$ 300$ each, 100 medium-cost patients at $\$ 200$ each, and 100 lowcost patients at $\$ 100$ average to $\$ 198.31$ per patient.

\section{Table 1}

medium-cost patients, and 100 low-cost patients paying a $\$ 198.31$ premium under Firm B’s plan, and 95 high-cost patients, 100 medium-cost patients, and 110 lowcost patients paying a $\$ 195.08$ premium in Firm A's plan. ${ }^{5}$ This sequence of events is illustrated in Table 1 below. This trend would continue as more hepatitis $\mathrm{C}$ patients choose Firm B's plan and then make the move to Firm A's (or a similar plan that does not cover Sovaldi) once cured. This adverse effect on Firm B's plan is enhanced by the

595 high-cost patients at $\$ 300$ each, 100 medium-cost patients at $\$ 200$ each, and 100 lowcost patients at $\$ 100$ average to $\$ 198.31$ per patient. 95 high-cost patients at $\$ 300$ each, 100 medium-cost patients at $\$ 200$ each, and 110 low-cost patients at $\$ 100$ average to $\$ 195.08$ per patient. This is achieved by the ten high-cost hepatitis C patients in Firm B's plan becoming ten low-cost healthy patients in Firm A’s plan.

\begin{tabular}{lccccc} 
& & $\begin{array}{c}\text { Low-Cost } \\
\mathbf{( \$ 1 0 0 )}\end{array}$ & $\begin{array}{c}\text { Medium-Cost } \\
\mathbf{( \$ 2 0 0 )}\end{array}$ & $\begin{array}{c}\text { High-Cost } \\
\mathbf{( \$ 3 0 0 )}\end{array}$ & Premium \\
$\begin{array}{l}\text { Individuals are even- } \\
\text { ly distributed across } \\
\text { Plan A and Plan B }\end{array}$ & Firm A & 100 & 100 & 100 & $\$ 200$ \\
\hline $\begin{array}{l}\text { Firm B starts cov- } \\
\text { ering Sovaldi. Five } \\
\text { high-cost HCV } \\
\text { patients move from }\end{array}$ & Firm A & 100 & 100 & 100 & $\$ 200$ \\
$\begin{array}{l}\text { Firm A to Firm B } \\
\text { seeking Sovaldi. }\end{array}$ & & 100 & & & \\
$\begin{array}{l}\text { There are now ten } \\
\text { HCV patients with }\end{array}$ & Firm B & 100 & 100 & 105 & $\$ 198.31$ \\
$\begin{array}{l}\text { Firm B } \\
\text { Firm B }\end{array}$ & & & & & \\
\end{tabular}

\begin{tabular}{|c|c|c|c|c|c|}
\hline $\begin{array}{l}\text { The ten HCV pa- } \\
\text { tients are cured and } \\
\text { are low-cost. No lon- }\end{array}$ & Firm A & 110 & 100 & 95 & $\$ 195.08$ \\
\hline $\begin{array}{l}\text { and seeing Firm A's } \\
\text { lower premiums, } \\
\text { they move to Firm A }\end{array}$ & Firm B & 100 & 100 & 95 & $\$ 198.31$ \\
\hline
\end{tabular}


other low- and medium-cost patients who may choose to move to Firm A's plan due to the lower premiums. The simple solution for Firm B to avoid this adverse selection is to not cover Sovaldi at all.

This model is oversimplified and does not include myriad real-world factors such as open enrollment periods, deductible and copayment structures, and the number of plans in the market. However, the model illustrates why health insurance plans may be hesitant to cover these high-cost cures. Unlike coverage problems for treatments of intractable diseases, in which long-term adverse selection costs deter insurance companies from covering therapies, this market failure is due to uncertainty over whether high-cost patients will stay on the plan after becoming low-cost patients.

While this type of adverse selection problem is a very real concern for insurers, there is little evidence it has affected coverage of Sovaldi within Medicare Part D (Brennan and Wilson 2014). According to a December 2015 Kaiser study, all of the selected Medicare Part D PDPs covered Sovaldi within their formularies (Hoadley, Cubanski, and Neuman 2015). However, these data are unlikely to be indicative of the whole insurance market. The Kaiser study only covered a subset of Medicare Part D PDPs, and did not include private plans, which are structured using different rules and regulations. For example, Medicare PDPs are required to include at least two drugs from each USP drug class within their formulary, resulting in likelier coverage of most innovative therapies (CMS 2016). Additionally, since Sovaldi and similar hepatitis $C$ medications are the only curative therapy currently raising this problem for insurance plans, it is very possible the arrival of additional curative therapies will exacerbate the situation. Finally, Sovaldi cures a common disease, leading to more frequent uses of the therapy, and a greater public backlash if it is not covered. There is no guarantee gene therapies for rare diseases would enjoy the same insurance treatment. With the arrival of even higher cost gene therapies for rare diseases, adverse selection concerns may result in widespread market failures.

\section{POLICY OPTIONS TO ADDRESS MARKET FAILURES FROM ADVERSE SELECTION}

There are several options that policymakers can pursue to ensure that patients can access these breakthrough cures, including expansions of government health insurance programs, added requirements for beneficiaries, "pay-for-performance" structures, and risk-stabilization techniques.

Policymakers could expand governmentrun health insurance programs such as Medicaid, Medicare, TRICARE, and CHIP to cover all chronic-disease patients who are having difficulty accessing cures in the private health insurance market. This option may be particularly popular among individuals who support a single-payer health insurance system, or even just a strong governmental role in public health, but the exorbitant cost renders it politically infeasible.

In 2013, the consulting company Milliman estimated that by 2016 there would be 2.35 million individuals with hepatitis C (not counting the prison population) in need of treatment. Of these 2.35 million individuals, 1.09 million would be covered by public insurance, 
836,220 individuals would be covered by private insurance, and 439,320 individuals would be uninsured. Please see Appendix 1 for the full table from Milliman's report. Medicaid programs are already facing sizable increases in hepatitis $C$ spending (Barlas 2015). Through the first three quarters of 2014 , states spent $\$ 1.08$ billion on Sovaldi, the third-largest drug expenditure behind Abilify, an anti-psychotic, and the cholesterol-lowering Lipitor (Walker 2015). Expanding government coverage to the almost 1.3 million privately insured and uninsured individuals seeking Sovaldi at the estimated discounted price of $\$ 54,000$ per patient would cost nearly $\$ 70$ billion, and would face stiff political opposition (Milliman 2013; Silverman 2015). ${ }^{6}$ This estimate does not even account for the many gene therapies that will arrive soon, only increasing the number of patients requesting high-cost cures (Johnson and Dennis 2015).

A second option is to change the regulations governing health insurance to allow health insurance plans to prohibit individuals who access these cures from switching plans following treatment. This would allow the health insurance plan to recoup their costs through premiums charged to these now low-cost individuals. This is also problematic since it limits patient choice and could lead to extensive medical debt if patients cannot afford to pay their premiums, but are unable to leave their plan.

"Pay-for-performance" structures and risk-stabilization techniques are much more politically feasible and palatable to insurers.

6 The estimated 836,220 privately insured individuals plus the estimated 439,320 uninsured individuals equal 1,275,540 non-publicly insured individuals. At $\$ 54,000$ each, the total cost of Sovaldi for these individuals is $\$ 68,879,160,000$.
POTENTIAL SOLUTION:

RISK-STABILIZATION

PROGRAMS FOR PLANS

COVERING EXPENSIVE

\section{CURES}

Policymakers could turn to already established risk-stabilization programs existing under Medicare Part D and the ACA as models for a solution. The ACA in particular contains three riskstabilization programs intended to assuage insurers' concerns about joining the newly established health insurance marketplaces. The permanent risk-adjustment provision in the ACA requires "Insurers with higher shares of low-cost enrollees to contribute to a fund that will make payment to insurers with larger shares of high-cost enrollees" (American Academy of Actuaries 2013). The other two ACA risk-stabilization programs, the transitional reinsurance program and the risk corridors program, are both temporary three-year programs that attempt to address adverse selection resulting from the dearth of information on these new health insurance marketplaces. They do not present a sustainable and effective solution to the problem of adverse selection arising from coverage of highcost, short-term therapies. The permanent risk-adjustment program attempts to address a situation most analogous to the problem this paper addresses. Temporary programs and are not directly relevant to this discussion.

The federal government could introduce a pilot risk-adjustment program in certain health insurance markets for insurers who cover these expensive treatments. The program would provide payments to insurers covering the highcost treatments in an amount necessary to 
avert the risk associated with that coverage. If the pilots are found to be successful, a larger federal program that incorporates all private small and large group plans should be adopted. Exploration of expanding this program into self-insured plans could also occur. Much like the program under the ACA, the insurers covering these cures would be protected against having to drastically raise premiums or incur substantial losses resulting from the adverse selection of covering these cures. This program would also be budget neutral as it could be funded by fees collected from the entire pool of insurers regardless of whether they cover the treatments. Payments from the program would allow insurers to cover the treatments without imposing significant premium increases, and thus avoid losing healthy posttreatment individuals from their plans who would otherwise leave for cheaper plans with narrower coverage. This riskadjustment program would need to be carefully constructed as risk-adjustment programs, particularly the ACA's riskadjustment program, are prone to over and under-payments (Weiner, Trish, Abrams, and Lemke 2012).

A final criterion for insurers to meet to be covered by this risk-adjustment program is that they must require affordable, non-prohibitive copayments from their beneficiaries for these treatments. High coinsurance discourages individuals from choosing these plans, and often forces individuals to skip doses or forgo treatment altogether (Nelson 2014; Dusetzina et al. 2013). If insurers' risk in covering these drugs is largely covered by this riskadjustment program, they should ask for fair copayments from their beneficiaries.
POTENTIAL SOLUTION: ANNUITY-LIKE "PAY-FORPERFORMANCE" PAYMENT MODELS

Policymakers could also consider the development of payment models that allow health insurers to avoid paying for the high-cost therapy in one expensive upfront payment. Instead, the insurers would pay for treatments over several years, contingent on the drug's performance for each patient. As Beasley (2015) explains, "Under this model, the price would be amortized over a period of time and contingent on proof that the treatment is effective and safe". In September 2014, Troyen A. Brennan and James M. Wilson (2014) argued: "A pay-for-performance model based on the thoughtful development of efficacy metrics that can be transferred between succeeding insurers seems to present a reasonable and practical solution."

This option provides a variety of benefits. First, insurers' concerns regarding the long-term efficacy of gene therapy would be assuaged by making the payments contingent upon the therapy's performance. Second, these annuity payments could be portable across insurers if the patient decides to switch. This model could ease adverse selection concerns, as insurers would not pay high upfront costs and might be less concerned about potentially losing patients to other plans once cured. Finally, these annuity "payment streams could eventually be packaged and sold to investors, as happens now with securities backed by financial assets like credit card receivables" (Beasley 2015).

While this approach offers the many benefits described above, it also presents many complications. First, it is still 
unclear how the pharmaceutical health insurance industry would react to such a system. This approach is different enough from the status quo to make either entity uncomfortable and unwilling to participate in the new system. Second, legislation would be required to create the new system. Currently, no regulatory framework is set up to allow for the portability of such annuity payments across insurers. Portability of annuity payments could be even more complicated if the patient changes from private to public insurance, or vice versa. There could also be intense disagreement on what drugs would qualify, and the level of health upon which annuity payments are contingent.

Still, this approach promises a potential market-based solution that is likely palatable to all parties involved, and affords patients access to the curative treatment.

\section{CONCLUSION}

With the advent of cures for chronic diseases, health insurers face new adverse selection concerns regarding "cured" individuals leaving the plan in search of cheaper alternatives following the completion of treatment. Insurers are justifiably concerned that covering these high-cost treatments will raise premiums and potentially start the "death spiral" all insurers dread (Cutler and Zeckhauser 1997). Government intervention could solve this market failure. The enactment of a risk-adjustment program for plans covering high-cost cures could satisfy insurers' concerns with covering these drugs by covering increased costs due to the adverse selection issues described in this paper. Annuity-like "pay-forperformance" plans could also spread out drug payments over time and provide portability to future insurers while making payments contingent on performance. These solutions are favorable for each party involved: insurers are covered from incurring heavy losses, pharmaceutical companies are able to sell their treatments, the government does not incur any additional costs, and most importantly, patients are able to access these lifesaving and revolutionary cures.

\section{REFERENCES}

Academy of Managed Care Pharmacy. 2013. "HHS Finalizes Rule for Prescription Drug Benefit Design under Essential Health Benefits to Implement Affordable Care Act Provisions and Clarifies Preventive Coverage for Certain OTC Items". February 21, 2013. Accessed February 28, 2016. http://amcp.org/WorkArea/ DownloadAsset.aspx?id=16173

Actuarial Soundness Board. 2015. "Definitions from ASOPs and ACGs of the ASB". March 2015. Accessed March 1, 2016. http://www.actuarialstandardsboard.org/ wp-content/uploads/2015/03/ASB-definitions-March-2015.pdf 
Adult Congenital Heart Association et al. 2010. Pre-existing Conditions Draft Statement, January 14, 2010. Letter. Accessed February 28, 2016. http:// www.nationalhealthcouncil.org/sites/default/files/NHC_Files/Pdf_Files/ GroupLetterHealthCareReformConference_01-21-10.pdf

AHIPCoverageAdmin. AHIP Coverage (blog). America's Health Insurance Plans. http:// www.ahipcoverage.com/2014/05/20/yikes-1000-per-pill/.

Akerlof, George A. 1970. "The Market for "Lemons": Quality Uncertainty and the Market Mechanism.” Quarterly Journal of Economics 84 (3): 488-500.

American Academy of Actuaries. 2013. "Fact Sheet: ACA Risk-Sharing Mechanisms." Accessed May 3, 2015. http://actuary.org/files/ACA_Risk_Share_Fact_Sheet_ FINAL120413.pdf

Appleby, Julie. 2014. “There's a Life-Saving Hepatitis C Drug. But You May Not Be Able To Afford It." Kaiser Health News. March 3, 2014. Accessed May 3, 2015. http:// kaiserhealthnews.org/news/insurers-debate-who-should-get-costly-hepatitis-cdrug/

Avalere Health. 2014. "Avalere Analysis: Consumers Face More Hurdles to Accessing Drugs in Exchange Plans Compared to Employer Coverage." March 24, 2014. Accessed November 26, 2015. http://avalere.com/expertise/life-sciences/ insights/more-controls-on-drug-access-in-exchanges

Barlas, Stephen. 2015. "States Try to Control Medicaid Pharmaceutical Costs: Numerous, Diverse Cost Pressures Force Myriad Reform Efforts.” Pharmacy and Therapeutics 40 (4): 260-262. Accessed November 27, 2015. http://www. ncbi.nlm.nih.gov/pmc/articles/PMC4378518/

Beasley, Deena. 2015. "Paying for gene therapy: are annuities the next big thing?" Reuters February 19, 2015. Accessed March 3, 2016. http://www.reuters.com/ article/us-usa-healthcare-payments-idUSKBN0LN08H20150219

Bentley, T. Scott. 2014. "2014 Organ and Tissue Transplant Cost Estimates and Discussion." Milliman, Inc. December 2014. Accessed May 2, 2015. http://www. milliman.com/uploadedFiles/insight/Research/health-rr/1938HDP_20141230. pdf

Brennan, Troyan A. and James M. Wilson. 2014. "The Special Case of Gene Therapy Pricing", Nature Biotechnology 32: 874-876. 
Burger, Ludwig and Ben Hirschler. 2014. "Exclusive: First Gene Therapy Drug Sets Million-Euro Price Record.” Reuters, November 26. Accessed May 3, 2015. http://www.reuters.com/article/2014/11/26/us-health-genetherapy-priceidUSKCN0JA1TP20141126

The Center for Consumer Information and Insurance Oversight (CCIIO). 2015. "Information on Essential Health Benefits (EHB) Benchmark Plans." Accessed January 23, 2016. https://www.cms.gov/cciio/resources/data-resources/ehb.html

. 2015. “The Transitional Reinsurance Program - Reinsurance Contributions.” Accessed March 3, 2016. https://www.cms.gov/CCIIO/Programs-andInitiatives/Premium-Stabilization-Programs/The-Transitional-ReinsuranceProgram/Reinsurance-Contributions.html

The Centers for Disease Control and Prevention (CDC). "Chronic Disease Prevention and Health Promotion.” Accessed May 2, 2015. http://www.cdc.gov/ chronicdisease/

. 2015. "Hepatitis C Information for the Public.” Last updated April 15, 2015. Accessed May 2, 2015. http://www.cdc.gov/hepatitis/C/cFAQ.htm\#cFAQ41

The Centers for Medicare and Medicaid Services (CMS). 2015. "Medicare Provider Utilization and Payment Data: Part D Prescriber." Accessed May 2, 2015. http:// www.cms.gov/Research-Statistics-Data-and-Systems/Statistics-Trends-andReports/Medicare-Provider-Charge-Data/Part-D-Prescriber.html

. 2016. "Medicare Prescription Drug Benefit Manual: Chapter 6 - Part D Drugs and Formulary Requirements." Accessed January 28, 2016. https://www.cms. gov/Medicare/Prescription-Drug-Coverage/PrescriptionDrugCovContra/ Downloads/Part-D-Benefits-Manual-Chapter-6.pdf

Cutler, David M. and Richard J. Zeckhauser. 1997. "Adverse Selection in Health Insurance." National Bureau of Economic Research Working Paper 6107. Accessed May 3, 2015. http://www.nber.org/papers/w6107.pdf

Denenberg, H.S. et al. 1964. Risk and Insurance. Englewood Cliffs, Prentice Hall.

Dickerson, O.D. 1959. Health Insurance, Homewood, Irwin.

Dusetzina, Stacie B. et al. 2013. "Cost Sharing and Adherence to Tyrosine Kinase Inhibitors for Patients With Chronic Myeloid Leukemia." Journal of Clinical Oncology 32 (4): 306-311. doi: JCO.2013.52.9123. 
Einav, Liran and Amy Finkelstein. 2011. "Selection in Insurance Markets: Theory and Empirics in Pictures." Journal of Economic Perspectives 25 (1): 115-138.

Fitch, Kathryn et al. 2013. "Healthcare Reform and Hepatitis C: A Convergence of Risk and Opportunity." Milliman Inc., December 10, 2013. Accessed May 2, 2015. http://us.milliman.com/uploadedFiles/insight/2013/convergence-of-risk-andopportunity.pdf

Gilead Sciences. 2015. "SOVALDI Combination Therapy Cure Rates in Clinical Studies". Accessed January 23, 2016. http://www.sovaldi.com/about-sovaldi/study-results

Heavey, Susan. 2014. "US drug industry group defends price of Gilead hepatitis drug". Reuters. April 10, 2014. Accessed February 28, 2016. http://www.reuters.com/ article/us-hepatitis-gilead-phrma-idUSBREA391I220140410

Hoadley, Jack, Juliette Cubanski, and Tricia Neuman. 2015. "It Pays to Shop: Variation in Out-of-Pocket Costs for Medicare Part D Enrollees in 2016." The Henry J. Kaiser Family Foundation. December 2, 2015. Accessed January 23, 2016.

http://kff.org/medicare/issue-brief/it-pays-to-shop-variation-in-out-of-pocketcosts-for-medicare-part-d-enrollees-in-2016/

I AM (Still) ESSENTIAL Coalition. 2014. Coalition Letter to HHS Secretary

Sylvia Burwell, July 28 2014. Letter. Accessed November 26, 2015. http://www.theaidsinstitute.org/sites/default/files/attachments/ IAmStillEssentialBurwellltr_0.pdf

I Am Essential Coalition. 2014. Comments on Draft 2017 Letter to Issuers in the Federally-facilitated Marketplaces, January 17, 2016. Letter. Accessed January 23, 2016. http://www.theaidsinstitute.org/sites/default/files/attachments/2017\%20 Letter\%20to\%20issuers\%20I\%20Am\%20Essential\%20comment\%20letter.pdf

Johnson, Carolyn Y. and Brady Dennis. 2015. "Gene Therapies Offer Dramatic Promise but Shocking Costs.” The Washington Post, November 11, 2015. Accessed January 23, 2016. https://www.washingtonpost.com/business/economy/genetherapies-offer-dramatic-promise-but-shocking-costs/2015/11/11/01f11cf0824b-11e5-9afb-0c971f713d0c_story.html

Loftus, Peter. "Gilead Faces Suit Over Hepatitis Drug's Price”, The Wall Street Journal, December 10, 2014, Accessed January 23, 2016. http://www.wsj.com/articles/ philadelphia-transit-agency-sues-gilead-claiming-price-gouging-1418237153

Lotvin, Alan M. et al. 2014. "Specialty Medications: Traditional And Novel Tools Can Address Rising Spending On These Costly Drugs.” Health Affairs 33 (10): 17361743 
Millman, Jason. 2014. “The drug that's forcing America’s most important - and uncomfortable - health-care debate." The Washington Post, July 24, 2014. Accessed February 28, 2016. https://www.washingtonpost.com/news/wonk/ $\mathrm{wp} / 2014 / 07 / 24 /$ the-drug-thats-forcing-americas-most-important-anduncomfortable-health-care-debate/

Milliman, Inc. 2013. "Healthcare Reform and Hepatitis C: A Convergence of Risk and Opportunity." December 10, 2013. Accessed May 2, 2015. http://us.milliman. com/uploadedFiles/insight/2013/convergence-of-risk-and-opportunity.pdf

Nelson, Roxanne. 2014. "High Copayments Stymie Treatment Adherence in CML", Medscape, January 14, 2014. Accessed May 3, 2015. http://www.medscape.com/ viewarticle/819140

Silverman, Ed. 2013. “Tiger in the Fiscal Room: Beware the Increasing Cost And Number of Orphan Drugs." Managed Care, March 2013. Accessed January 23, 2016. http://www.managedcaremag.com/archives/2013/3/tiger-fiscal-roombeware-increasing-cost-and-number-orphan-drugs

. 2015. "What the 'Shocking' Gilead Discounts on its Hepatitis C Drugs Will Mean." The Wall Street Journal. February 4, 2015. Accessed March 3, 2016. http://blogs.wsj.com/pharmalot/2015/02/04/what-the-shocking-gileaddiscounts-on-its-hepatitis-c-drugs-will-mean/

United States Pharmacopeia. 2015. "USP Medicare Model Guidelines v6.0 \& v5.0." Accessed February 28, 2016. http://www.usp.org/usp-healthcare-professionals/ usp-medicare-model-guidelines/medicare-model-guidelines-v50-v40

Walker, Joseph. 2015. “Gilead's \$1,000 Pill is Hard for States to Swallow." Wall Street Journal, April 8, 2015. Accessed November 27, 2015. http://www.wsj.com/ articles/gileads-1-000-hep-c-pill-is-hard-for-states-to-swallow-1428525426

Weiner, Jonathan P., Erin Trish, Chad Abrams, and Klaus Lemke. 2012. "Adjusting for risk selection in state health insurance exchanges will be critically important and feasible, but not easy." Health Affairs, 31(2), 306-315. http://content. healthaffairs.org/content/31/2/306.full 
PAUL MELMEYER is a second-year Master of Public Policy student at the George Washington University concentrating in Regulatory Policy. He also serves in the Public Policy office of the National Organization for Rare Disorders (NORD) where he advocates for rare disease patients in Congress and administrative agencies. Following his completion of a Bachelor's degree in Political Science, also at GW, a year away from Foggy Bottom was too much to handle, resulting in his prodigal return. Outside of his public policy work, Paul enjoys following Pittsburgh sports teams and serenading his unfortunate neighbors on the violin.

\section{ACKNOWLEDGEMENTS}

The author is grateful to the following individuals for their contributions to this paper: Dr. Gerald Brock for his digestible and memorable education on adverse selection in health insurance, Associate Editor Ridhi Sahai for her months of fastidious review and editing, Editor-in-Chief Monika Jansen and Managing Editor Charlotte Nugent for their commitment to producing the highest quality product possible and their patience with my lifetime battle with deadlines, Dr. Suhui Li for graciously volunteering her time and expertise, my family for their unwavering support and offers of proofreading, Emily Russel for her encouragement and confidence in my abilities, and the National Organization for Rare Disorders for providing me with the invaluable opportunity to get to know many of the patients and their families who so desperately need a cure, and so unquestionably deserve one. 


\section{Appendix 1}

\section{APPENDIX D: DETAILED TABLES OF THE HCV POPULATION BY PAYER UNDER EACH SCENARIO FOR 2013-2020}

Table D-1: Payer Forecast of the U.S HCV Population under Status Quo Screening and Treatment

\begin{tabular}{|c|c|c|c|c|c|c|c|c|}
\hline Payer & 2013 & 2014 & 2015 & 2016 & 2017 & 2018 & 2019 & 2020 \\
\hline $\begin{array}{l}\text { Medicare } \\
\text { Non-Dual }\end{array}$ & 146,800 & 164,010 & 192,790 & 223,590 & 262,760 & 297,930 & 330,020 & 355,670 \\
\hline $\begin{array}{l}\text { Medicaid } \\
\text { Non-Dual }\end{array}$ & 349,250 & 432,530 & 444,010 & 424,230 & 393,040 & 363,540 & 334,240 & 307,120 \\
\hline $\begin{array}{l}\text { Dual } \\
\text { Eligible }\end{array}$ & 193,430 & 190,200 & 196,530 & 200,900 & 206,330 & 210,090 & 213,250 & 215,080 \\
\hline $\begin{array}{l}\text { Small } \\
\text { Group }\end{array}$ & 107,630 & 99,190 & 87,800 & 72,550 & 64,850 & 58,000 & 51,190 & 45,140 \\
\hline $\begin{array}{l}\text { Large } \\
\text { Group }\end{array}$ & 489,730 & 457,310 & 416,710 & 373,810 & 333,980 & 296,370 & 261,710 & 230,660 \\
\hline Individual & 92,360 & 75,470 & 63,740 & 52,690 & 42,580 & 37,640 & 33,070 & 29,050 \\
\hline $\begin{array}{l}\text { Exchange - } \\
\text { Platinum }\end{array}$ & 0 & 13,820 & 20,380 & 25,750 & 23,670 & 21,430 & 19,180 & 17,060 \\
\hline $\begin{array}{l}\text { Exchange - } \\
\text { Gold }\end{array}$ & 0 & 23,780 & 34,390 & 44,540 & 41,000 & 37,070 & 33,270 & 29,610 \\
\hline $\begin{array}{l}\text { Exchange - } \\
\text { Silver }\end{array}$ & 0 & 90,770 & 129,710 & 173,210 & 161,940 & 148,270 & 134,970 & 122,720 \\
\hline $\begin{array}{l}\text { Exchange - } \\
\text { Bronze }\end{array}$ & 0 & 45,670 & 69,890 & 93,680 & 88,290 & 80,950 & 73,930 & 67,300 \\
\hline $\begin{array}{l}\text { Veteran } \\
\text { Affairs }\end{array}$ & 275,770 & 261,860 & 248,110 & 234,470 & 220,970 & 208,040 & 195,480 & 183,380 \\
\hline $\begin{array}{l}\text { Other } \\
\text { Military }\end{array}$ & 9,500 & 8,860 & 8,040 & 7,250 & 6,590 & 6,010 & 5,360 & 4,750 \\
\hline Uninsured & $\underline{978.050}$ & $\underline{693,160}$ & $\underline{551,610}$ & $\underline{439,320}$ & $\underline{420,860}$ & $\underline{401,850}$ & $\underline{382.150}$ & $\underline{363,340}$ \\
\hline Total & $2,642,520$ & $2,556,630$ & $2,463,710$ & $2,365,980$ & $2,266,840$ & $2,167,170$ & $2,067,820$ & $1,970,890$ \\
\hline
\end{tabular}

Source: Milliman's analysis of NHANES, MarketScan 2010, Medicare 5\% Sample, and Medicaid Contributor data.

Totals may not match due to Rounding

Does Not Include Prison Population 